\title{
Articles
}

The Person and the Challenges

Volume 5 (2015) Number 2, p. 5-32

DOI: http://dx.doi.org/10.15633/pch.1502

Graham Rossiter

Australian Catholic University, Sydney

\section{A Case for a 'Big Picture' Re-Orientation of K-12 Australian Catholic School Religious Education in the Light of Contemporary Spirituality}

\begin{abstract}
This is the second of two articles that argue a case for a 'big picture' re-orientation of Australian Catholic school K-12 religion curricula. The first article ${ }^{1}$ considered that there has been such a great change in the landscape of contemporary spirituality that the traditional framework of religious meanings within which Catholic school religion curricula are written is out of synch with the meanings that inform contemporary spiritualities. A proposed responsive change in orientation suggests that more prominence needs to be given to the critical interpretation and evaluation of cultural meanings, while not neglecting the more traditional aim of giving young Catholics meaningful access to their religious heritage. The apparently different estimates of spirituality for children and adolescents also need to be taken into account. If many of the pupils in Catholic schools will never become actively involved in parishes when they grow up, then religious education needs to offer more than familiarising them with Catholic theology and religious practice; it also needs to equip them with skills to address the spiritual and moral issues they will encounter in life. Attention is given to what this entails in both content and pedagogy, at primary and secondary levels.
\end{abstract}

\section{Keywords}

Australia, Catholic Religious Education, youth, spirituality. 


\section{Introduction}

Because of significant changes in the landscape of spirituality ${ }^{2}$ religious educators in Australian Catholic schools face a challenging dilemma; in all likelihood this same situation applies to Catholic schools in some other Westernised countries. They set out to educate young people in the Catholic tradition, through a religion curriculum framed within traditional Catholic cultural-religious meanings. However, most of their students have little identification with this authoritative view. Rather, in tune with the very different cultural meanings that frame their thinking, they tend to regard religion as an optional resource for living, like potentially useful infrastructure - but very much in the background ${ }^{3}$. While many youth accept that religion may be attractive and useful for the religiously inclined, they have little doubt that it is largely irrelevant to their own needs, interests and lifestyles. Most young people say they still believe in God, as a kind of benign 'therapist-in-the-sky' who can be asked for help when it is really needed ${ }^{4}$; and they retain a nominal religious identification - they are not anti-religious. They accept religious education without antipathy because they see it as an established part of their Catholic schooling which they value highly. But usually for senior students, there is not much serious engagement with religious education because they feel it is not relevant to their lives, and in any case, it is hardly a subject with the same academic credentials as those that 'count' like English, Maths etc. ${ }^{5}$

2 G. M. Rossiter, Religious education and the changing landscape of spirituality: Through the lens of change in cultural meanings, "Journal of Religious Education" (2010) 55 (2); M. Mason, A. Singleton \& R. Webber, The spirit of Generation Y: Young people's spirituality in a changing Australia, Melbourne 2007, John Garratt; D. Tacey, Reenchantment: The new Australian spirituality, Sydney 2000, Harper Collins; D. Tacey, The spirituality revolution: The emergence of contemporary spirituality, Sydney 2003: Harper Collins.

3 C. Smith \& M. L. Denton, Soul searching: The religious and spiritual lives of American teenagers, Oxford 2005, Oxford University Press, p. 128; While it is beyond the scope of this article to give a detailed account of research on youth spirituality, some key points will be signposted to highlight the difference from traditional religious spirituality. Cf. G. M. Rossiter, Religious education and the changing landscape of spirituality: Through the lens of change in cultural meanings, "Journal of Religious Education" (2010) 55 (2).

4 C. Smith \& M. L. Denton, Soul searching: The religious and spiritual lives of American teenagers, Oxford 2005, Oxford University Press, p. 162; M. Mason, A. Singleton \& R. Webber, The spirit of Generation Y: Young people's spirituality in a changing Australia, Melbourne 2007, John Garratt, p. 82.

M. L. Crawford \& G. M. Rossiter, Reasons for living: Education and young people's search for meaning, identity and spirituality. A handbook, Melbourne 2006, Australian Council for Educational Research, p. 307. 
However, this challenging account of spirituality refers specifically to adolescents and young adults. At first sight, this does not seem to be congruent with what is said about the spirituality of children, where there is a much more optimistic account of their openness to the spiritual and to religion - with interest, enthusiasm and ready engagement ${ }^{6}$.

For secondary school religion teachers, with a hiatus between expectations and the reality of teenage spirituality, teaching religion in Catholic schools can feel like a 'health hazard'7 . Much of their diocesan support for religion teachers encourages them to try harder to make the religious package more attractive, to ignite students' interest and participation in the $\mathrm{Church}^{8}$; but this formula does not adequately identify the problem, let alone address it effectively.

On the contrary, anecdotal evidence suggests that many Catholic primary school teachers (and some junior secondary teachers) feel that teaching religion is 'a breeze' - successful, effective and enjoyable with responsive pupils. One might get the impression that they are teaching a 'different species' from the adolescents taught in senior secondary classes.

Following up the interpretation of fundamental historical changes in contemporary spirituality in terms of shifts in cultural meanings ${ }^{9}$, the following will propose some broad, general implications for the K-12 Catholic school religion curriculum, mainly from this perspective of the more adolescent/adult spirituality; and then it will address briefly the differences needed at primary school / junior secondary levels, that are related to children's spirituality. The argument begins with the claim by Rossiter ${ }^{10}$, that a successful Catholic school religious education in the traditional sense is no longer adequate, nor even possible, in Australia (and this is probably also the case in some other countries). Aiming relatively exclusively at reproducing what is currently considered a traditional Catholic spirituality is

6 E.g. D. Hay \& R. Nye, The spirit of the child, London 1998, Harper Collins; Adams et al. 2008; B. Hyde, Children and spirituality: Searching for meaning and connectedness, London 2008, Jessica Kingsley.

D. Kenyon, What constitutes success in classroom religious education? A study of secondary religion teachers' understandings of the nature and purposes of religious education in Catholic schools, Unpublished PhD Thesis, Australian Catholic University, Sydney 2010, p. 234.

8 E.g. Catholic Bishops of NSW \& ACT, Catholic schools at a crossroads: Pastoral letter of the Bishops of NSW and the ACT, Sydney 2007, Catholic Education Office.

9 G. M. Rossiter, Religious education and the changing landscape of spirituality: Through the lens of change in cultural meanings, "Journal of Religious Education" (2010) 55 (2).

${ }^{10}$ G. M. Rossiter, Religious education and the changing landscape of spirituality: Through the lens of change in cultural meanings, "Journal of Religious Education" (2010) 55 (2), p. 26. 
not relevant to most pupils (Note: is this the same as the typical spirituality of most religion teachers?). There is a need to re-orient Catholic school religious education more in the direction of trying to enhance the basic human spirituality of young people, whether or not they engage with a parish.

However, the radical change in contemporary spirituality does not require a radical change in religion curricula, but rather a subtle one. There needs to be a greater emphasis on critical/interpretive/evaluative activity. In the classroom, religion needs to be treated more as a valuable but contentious area to investigate, than as a set of beliefs that the students should accept and adopt. This does not mean abandoning the teaching of traditions because good access to one's historical religious tradition is not only a birthright, but a spiritual resource that serves as a starting point in a lifelong search for meaning, purpose and value in life.

\section{How a religiously sponsored education might enhance a relatively secular youth spirituality - probing the relationships between the spiritual and the religious}

A Catholic religious education that can enhance youth spirituality needs a way of understanding the relationships between the spiritual and the religious, and between spirituality and religiosity. The word and phrases 'faith', 'faith development' and 'education in faith', while always important in Catholic religious education, have not been included in this analysis because their relationship with spirituality needs substantial attention that is beyond the scope of this article. While faith has belief, emotional and commitment dimensions, it is the 'trusting relationship with God' that is central to the Christian understanding of faith. This makes faith like the long-term, 'hoped for', very personal outcome of Catholic religious education. Spirituality, as an intermediate construct that is intimately related to faith, can be useful when dealing more directly with content and pedagogy - as explained in more detail elsewhere ${ }^{11}$. They argued that the construct spirituality is a useful one for contemporary theory and practice of religious education, while also having currency with respect to the more general spiritual / moral dimension to the whole school curriculum. The

11 M. L. Crawford \& G. M. Rossiter, Reasons for living: Education and young people's search for meaning, identity and spirituality. A handbook, Melbourne 2006, Australian Council for Educational Research. 
notion of a 'basic human spirituality' will be used, rather than 'human faith' as described by Fowler ${ }^{12}$, even though there is a significant overlap between the two; it is interesting to note that the subtitle to Fowler's book on faith development was "The psychology of human development and the quest for meaning".

Table one gives a brief account of each of the selected constructs in broad outline. There is an extensive literature that discusses spirituality and the relationship between the spiritual and the religious ${ }^{13}$.

Table 1. Summary of relationships between the constructs spiritual, religious, spirituality and religiosity

\begin{tabular}{|c|c|}
\hline $\begin{array}{l}\text { Spiritual } \\
\text { The spiritual is the natural dimension to life that } \\
\text { includes: thinking and feelings about transcendence; } \\
\text { ideas about a creator or creative force in the cosmos; } \\
\text { human values; sense of meaning and purpose to } \\
\text { life; love and care for self and others; sense of } \\
\text { stewardship for the earth and its flora and fauna; the } \\
\text { aesthetic. }\end{array}$ & $\begin{array}{l}\text { Religious } \\
\text { Being religious means being spiritual in a particular } \\
\text { way as informed by the beliefs, practices and } \\
\text { traditions of a religious group. It usually includes } \\
\text { a sense of personal relationship with god, belief in } \\
\text { an afterlife and identification with, and participation } \\
\text { in a local religious community. The religious is } \\
\text { usually informed by a theology; and it participates in } \\
\text { a ritual life and prayer, as well as relating to religious } \\
\text { symbols, art and music. }\end{array}$ \\
\hline $\begin{array}{l}\text { Spirituality } \\
\text { Spirituality is the way in which a spiritual/moral } \\
\text { dimension enters into, or is implied in, the thinking } \\
\text { and behaviour of individuals. }\end{array}$ & $\begin{array}{l}\text { Religiosity (or religious spirituality) } \\
\text { Religiosity is a religious spirituality with engagement } \\
\text { in religious activities and thinking; personal and } \\
\text { communal prayer and participation in religious rituals } \\
\text { in a community of faith are prominent. Religiosity is } \\
\text { a spirituality that is clearly referenced to religion. }\end{array}$ \\
\hline
\end{tabular}

Drawing on the argument developed by Rossiter ${ }^{14}$, a scheme relating basic human spirituality and religious spirituality is proposed to suggest why a change of emphasis is needed in Catholic religious education. This will imply a simplification that masks the complexity and mystery in people's spirituality,

12 J. W. Fowler, Stages of faith: The psychology of human development and the quest for meaning, San Francisco 1981, Harper \& Row.

13 Some example references are: M. L. Crawford \& G. M. Rossiter, Reasons for living: Education and young people's search for meaning, identity and spirituality. A handbook, Melbourne 2006, Australian Council for Educational Research; R. C. Fuller, Spiritual, but not religious: Understanding unchurched America, New York 2001, Oxford University Press; R. Otto, The idea of the holy: The idea of the holy: An inquiry into the non-rational factor in the idea of the divine and its relation to the rational (English 2nd Edn.), New York 1950, Oxford University Press; D. Tacey, Reenchantment: The new Australian spirituality, Sydney 2000, Harper Collins; D. Tacey, The spirituality revolution: The emergence of contemporary spirituality, Sydney 2003, Harper Collins.

${ }_{14}$ G. M. Rossiter, Religious education and the changing landscape of spirituality: Through the lens of change in cultural meanings, "Journal of Religious Education" (2010) 55 (2). 
but nevertheless is useful educationally. A religious spirituality is considered to be a basic human spirituality that has an overlay of cultural religious meanings. These meanings can motivate, inspire, and enhance human spirituality - while it may be difficult for individuals to discern the precise level of influence that religion has on them. Religious people can report that spirituality is the driving force in their lives; nevertheless, in some instances, one can observe individuals who maintain they are religious, but their religion appears to be relatively nominal and superficial because other human motivations seem to dominate their behaviour. Care is needed not to be too judgmental. Expecting religious people to be perfect psychologically is unrealistic. All people are flawed and handicapped to some extent; being religious - as well as being courageous, committed, faithful, creative or psychologically healthy - is not incompatible with having lifelong psychological problems. This is the human condition. However, people tend to be quick to see hypocrisy where those who publicly proclaim they are religious behave in ways that contradict the values professed in their religious stance.

The focus here is not on trying to unravel the mysterious relationship between psychological and religious influences on individuals; it tries to highlight the prominence of cultural meanings in spirituality - it will be religious or not depending on what cultural meanings serve as dominant reference points. How cultural meanings can be identified and studied then becomes a central component of religious education. A healthy spirituality (whether religious or not) may depend on which cultural meanings inform people's thoughts and actions and on the extent of their influence on lifestyle and wellbeing; hence these meanings need to be evaluated in the light of community values to get some indication of how they might enhance or harm the quality of people's lives ${ }^{15}$.

One might ask: would young people make sense of this differentiation between the spiritual and the religious? If they are not formally religious, young people tend to think they have no spirituality at all; for many, the religious and the spiritual are much the same ${ }^{16}$. This view is often held by religious people who use the word 'unchurched' to describe such youth ${ }^{17}$. This apparent identification of

15 M. L. Crawford \& G. M. Rossiter, Reasons for living: Education and young people's search for meaning, identity and spirituality. A handbook, Melbourne 2006, Australian Council for Educational Research, p. 198.

16 C. Smith \& M. L. Denton, Soul searching: The religious and spiritual lives of American teenagers, Oxford 2005, Oxford University Press, p. 78.

17 R. C. Fuller, Spiritual, but not religious: Understanding unchurched America, New York 2001, Oxford University Press. 
the spiritual and the religious remains common even though there is a growing interest in the notion of a spirituality not necessarily connected with religion ${ }^{18}$. From the analytical perspective taken here, many young people are spiritual but not religious as they retain a spiritual dimension in their values. This needs to be distinguished from the way the term 'spiritual but not religious' is used by researchers like Smith \& Denton ${ }^{19}$ and Fuller ${ }^{20}$, where it described individuals who were active 'spiritual seekers', trying to purposefully construct a spirituality that was independent of religion. Most young people are not like this; they just appear disinterested in religion; what they are interested in is the feel-good experience and lifestyle.

The style and pace of life in contemporary, Westernised, industrialised societies has changed the way that many people (including youth) relate to religious meanings; many get by without much reference to them. People may remain nominally identified with a denomination or religion; nevertheless, they pay little attention to it because its meanings seem to have little connection with their everyday living. While previously 'obedience to God' was prominent, now this is eclipsed by concerns to 'live one's life to the full' - and little thought would be given to the potential overlap between these two ideas. Hence there has been a significant change in the locus of spirituality. It appears to have moved away from religiosity, where it was relatively easily identified in formal religious activities including prayer and liturgy. But where has it gone? Some judge that it has disappeared, and where this happens there is no spirituality. Others suggest that it has moved into the personal lives of individuals, becoming more subjective and individualistic. However, the idea of conscious 'movement' does not seem to describe meaningfully what has happened. The decline in engagement with religious meanings simply leaves human spirituality in its 'raw' state, de facto. It has not gone anywhere; it has just lost its cultural religious overlay - for better or for worse.

This interpretation sees spirituality as always embedded in people's thoughts and actions; but without a religious overlay, it is more implied than overt; it is therefore

18 M. L. Crawford \& G. M. Rossiter, Reasons for living: Education and young people's search for meaning, identity and spirituality. A handbook, Melbourne 2006, Australian Council for Educational Research, p. 179; R. Coles, The spiritual life of children, London 1992, Harper Collins; D. Tacey, The spirituality revolution: The emergence of contemporary spirituality, Sydney 2003, Harper Collins.

19 C. Smith \& M. L. Denton, Soul searching: The religious and spiritual lives of American teenagers, Oxford 2005, Oxford University Press, p. 78.

20 R. C. Fuller, Spiritual, but not religious: Understanding unchurched America, New York 2001, Oxford University Press. 
difficult to identify because it is rooted in the psychology of the individual which is not fully open to public scrutiny. Determining what is 'spirituality' in people's lives is therefore naturally problematic, and this needs to be addressed in religious education; it means giving attention to the personal, subjective, psychological aspects of spirituality - and not just to the communal. Also needed is scrutiny of the cultural meanings that appear to influence people: Can they be identified? Are they healthy or harmful, depending on the extent of their influence? Hence a religious education that is beneficial to contemporary spirituality would need to include a search for the spiritual and moral dimensions in experience and events - this implies a search for spirituality followed by evaluation.

\section{General implications for religious education in the changed landscape of spirituality}

For many people, including youth, the fading of the cultural-religious overlay that informed a more overt religious spirituality left them with a residual, basic human spirituality. The words 'basic' and 'residual' should not be interpreted pejoratively as if this indicated little if any spirituality. Still, it remains difficult to pin down human spirituality because this involves a sort of 'mind reading' - theorising about which spiritual/moral meanings, if any, are affecting the individual. Hence it is necessary to acknowledge the natural uncertainty that goes with identification of human spirituality. This problem in interpreting what is the ultimate operative spirituality applies both to religious and non-religious people. For religious people, whether or not religion was a dominant influence, they could readily point to their religious cultural system as articulating the values and virtues that should be at the core of their behaviour. It is thus easier to identify someone's being religious than it is just being spiritual. Following the line of thinking in this paragraph has limited potential for religious education because it is so personal and subjective. It remains important for personal reflection and review of life, but religious education would do better to concentrate on the cultural meanings part of the equation, with the hope that this more objective focus may in turn prompt personal reflection.

Before leaving the area of personal/subjective spirituality, one further observation is pertinent. For religiosity, there was often a consciousness of the religious obligation or challenge to try to enhance and develop one's spirituality; this was one of the main purposes of prayer, worship and religious rituals. This 
makes a statement about the importance of a spiritual dimension to life; and it postulates that this spiritual dimension needs practice and active enhancement. There would be considerable variation in the extent to which individuals consciously took steps in personal reflection or in social action to enhance and practice their religious spirituality. This same variability would apply in a nonreligious, human spirituality. However, in the latter, the implied spirituality might not often be articulated by the individual; and this could easily lead to a neglect of the spiritual/moral dimension to life. Hence, the overt reminder to 'attend to the spiritual' within religious spirituality is a lesson that would be valuable for any human spirituality. Even for non-religious people, review of life, clarification of personal values and taking steps to foster a spiritual/moral viewpoint would be beneficial for them personally.

In re-orienting Catholic school religious education, two principal strategies will now be considered.

1. Access to the individual's inheritance of cultural religious meanings;

2. Critical interpretation and evaluation of culture.

\subsection{Access to young people's inheritance of cultural religious meanings: Studying the religious tradition}

Given the emphasis on basic human spirituality here and in Rossiter ${ }^{21}$, it may seem surprising that the first strategy refers explicitly to the teaching of religious traditions. But there is a good reason for this.

In terms of their lifelong search for meaning and purpose in life, children need to learn some basic familiarity with their own religious tradition, whether or not they will embrace this actively as adults. Children have a birthright to access their religious tradition; it is their cultural religious inheritance. It can give them some sense of the core spiritual meanings in the tradition - even if their parents or guardians have only a nominal religious identification. This gives children a starting cultural reference point for meaning in life that they can develop and change as they grow older and more capable of thinking for themselves. For children whose parents are atheist or agnostic, this principle still applies. While it could be expected that such parents would communicate to their children their particular views about the existence of god and about religion, nevertheless, they would be remiss if they did not help their children see that religion was intended to help

${ }^{21}$ G. M. Rossiter, Religious education and the changing landscape of spirituality: Through the lens of change in cultural meanings, "Journal of Religious Education" (2010) 55 (2). 
people find meaning and value in life, even if they, as parents, consciously wanted no association with religion. Some knowledge of the place of religions in culture and of their function in individuals' lives is a valuable part of the education of any citizen, religious or not. Without any initial religious meanings, children could grow up with a cultural deficit, like being raised in a partial vacuum of meaning (with a tabula rasa of spiritual resources). In effect, this would leave them to construct their own system of beliefs at an age when they are naturally more dependent on ready-made meanings ${ }^{22}$. No doubt they would already have familiarity with the values in the parental lifestyle, as well as exposure to the plurality of values implicit in the media and the social groups in which they participate.

Catholic school religious education contributes to pupils' cultural exposure to Catholicism; it can extend their cultural horizons beyond what they might absorb from their immediate home and community environment. This should also include knowledge of other religious traditions in the culture. Young people need some familiarity with their own tradition and knowledge of religions generally, even if at the time they may think this has little relevance for them.

Similarly, young people's identity development needs to be resourced by their religious tradition. Religious education can contribute to the communication of a basic sense of religious identity to children; this informs their initial selfunderstanding and interpretation of society. Later, when more mature, they would have their own say in determining their sense of identity and the extent to which any religious identification might apply.

While affirming the important place for the study of religious traditions, this strategy is not saying that the Catholic school religion curriculum is therefore adequate and should be left unchanged. The approach to teaching religious traditions needs to be modified - it needs more problem-posing content and a critical, student-centred, research-oriented pedagogy. More will be said about this in a later section.

\subsection{Critical interpretation and evaluation of culture}

Crawford \& Rossiter ${ }^{23}$ showed how the phrase 'search for meaning' has become more prominent in psychology and education since Viktor Frankl's

22 M. L. Crawford \& G. M. Rossiter, Reasons for living: Education and young people's search for meaning, identity and spirituality. A handbook, Melbourne 2006, Australian Council for Educational Research, p. 230.

${ }_{23}$ M. L. Crawford \& G. M. Rossiter, Reasons for living: Education and young people's search for meaning, identity and spirituality. A handbook, Melbourne2006, Australian Council for Educational Research. 
book Man's search for meaning was published in English in $1964^{24}$. It was said there was a contemporary 'crisis' in meaning, and education was considered to have some role in helping young people in their quest for meaning and purpose in life. But whatever this crisis might entail, it should not be interpreted as a lack of cultural meanings. As never before, there is a multiplicity of cultural meanings - all looking for adherents. And this in itself creates a problem for the individual's search for meaning. How to judge the appropriateness of cultural meanings and what criteria might be used therefore become important in education generally and in religious education in particular.

It is not enough for religious education to be concerned relatively exclusively with the handing on of Catholic cultural meanings. Since, for many young people, religion is no longer a major source of meaning, there is a need for their Catholic school religious education to look more critically at wide ranging cultural meanings. For example: conflicting meanings from different groups can be a root cause of prejudice and racism; frameworks of meaning can be sources of liberation or of domination; and the dissemination of meanings can insinuate the causes of particular economic and political interests. Learning how meanings are assigned and how they may need to be uncovered and appraised is a part of becoming wise. What young people need is not so much new cultural meanings but the capacity to evaluate them carefully, and this skill, practiced in religious education, can become a part of their lifelong learning. It can, not only help them in any dialogue with traditional religious meanings, but also with seeing where they stand with respect to various ideologies, political views and messages coming from different quarters, especially the commercial and entertainment worlds. Understanding cultural dynamics is a prerequisite for making judgments and considering possible social action.

Critical evaluation of culture has long been a concern of Catholic religious education. It was stressed in the encyclical Evangelii nuntiandi (Evangelisation in the modern world) by Pope Paul VI in 1976, and was regarded as important for youth ministry, adult education, missiology and theological education. Nevertheless, it has not been as prominent as it should be in the content of Catholic school religion curricula.

24 J. De Lors, (UNESCO), Learning the treasure within, Paris 1996, UNESCO International Commission on Education for 21st Century; T. P. Wong \& P. S. Fry (Eds.), The human quest for meaning: A handbook of psychological research and clinical applications, Mahwah 1998, Lawrence Erlbaum. 
Much has been written about education itself as a process of critical interpretation of culture. Critical theory and hermeneutics, including philosophical and sociological perspectives, have stressed the need for interpreting what is going on in culture; and in turn, this is proposed as a task to which public education can contribute ${ }^{25}$ to this role as the "interrogation of one's cultural conditioning". Young people are naturally very critical, but are often naive as regards the political, manipulative and exploitative aspects of culture; or if they are aware of exploitation, many may not worry too much as long as it does not affect their lifestyle.

Critical interpretation and evaluation of culture addresses the following:

- exploration of the shaping influence of culture on people's thinking and behaviour; appraisal of healthy and unhealthy effects;

- investigation of a range of contemporary social issues;

- identification of the influences on decisions and events; uncovering the historical, ideological and political forces at work, identifying who stands to gain or lose;

- deconstructing the components of writings so that they can be understood within their original contexts; this will inform potential meanings in different contexts;

- searching for the underlying economic and commercial interests that affect a situation;

- highlighting justice and environmental issues;

- calling ideologies to account.

This critical approach has also been referred to as an 'issues-oriented' religious education ${ }^{26}$. Crawford \& Rossiter $^{27}$ advocated this approach with examples of topics for the secondary religion curriculum. They considered that

25 M. L. Crawford \& G. M. Rossiter, Reasons for living: Education and young people's search for meaning, identity and spirituality. A handbook, Melbourne 2006, Australian Council for Educational Research, p. 264; B. V. Hill, A Time to Plant and a Time to Uproot: Values Education in the Secondary School, Sydney 1990, Sydney Anglican Education Commission, p. 3.

${ }^{26}$ M. L. Crawford \& G. M. Rossiter, Reasons for living: Education and young people's search for meaning, identity and spirituality. A handbook, Melbourne 2006, Australian Council for Educational Research; K. E. Nipkow, Pre-conditions for ecumenical and interreligious learning: Observations and reflections from a German perspective, Sydney 1991, Australian Catholic University Curriculum Research and Development Project in Religious Education.

27 M. L. Crawford \& G. M. Rossiter, Reasons for living: Education and young people's search for meaning, identity and spirituality. A handbook, Melbourne 2006, Australian Council for Educational Research, p. 394. 
it needed to enter into classroom practice across all year levels, while content and method need to be adapted to suit the maturity of pupils; a balance with other content was essential. They judged that this approach would enhance the perceived personal relevance of religious education. Generally, many Catholic youth and adults felt that the Catholic Church - and consequently its theology and religious education - had little relevance to life. They will quietly ignore Catholicism - and its religious education - unless they sense that something serious is being said about issues in personal, social, and political life. If there is not sufficient engagement with the real spiritual and moral issues of the day, they will get used to the expectation that their religion remains only marginally relevant to their lives. While religious education cannot be expected to resolve the problem - it cannot make the Catholic Church itself more relevant - it can endeavour to make the study of religion a more life-enhancing experience for pupils. And this requires an approach - in content, language and pedagogy - that realistically addresses young people's spirituality. This means identifying the ways they construct meaning, and helping them to critically appraise the principal cultural sources of that meaning; it sets out to alert them to the spiritual and moral aspects of life which can often be obscured beneath the all-engrossing contemporary concerns for personal wellbeing and happiness in a consumer oriented society. And it is within this context that the religious wisdom of Christianity can be effectively drawn into the educational process.

Making judgments about situations in the light of values, and the consideration of potential action to address social problems, are part of the process. In Catholic terminology, this is what is meant by the phrase 'evaluation from a gospel perspective'. Religion teachers should help pupils learn these evaluative skills, while at the same time modelling the process.

This approach has also been described in Catholic religious education as 'raising critical consciousness' or 'conscientisation'28 - words that were prominent in the discussions of catechesis by South American Catholic bishops in the 1960s and 1970s. Their documents had a wide influence within ministry and religious education ${ }^{29}$. It paralleled the impact on education by Paulo Freire's ideas on praxis (shared reflection and action) and the pedagogy

28 G. M. Rossiter, Religious education in Australian schools, Canberra 1981, Curriculum Development Centre, p. 117.

29 M. Warren, Source book for modern catechetics, Winona, MN 1983, St Mary's Press. 
of the oppressed ${ }^{30}$. It was also prominent in the area of critical pedagogy - the pedagogical application of critical theor $y^{31}$. These themes were reflected in Thomas Groome's approach to religious education - Shared Christian Praxis ${ }^{32}$. Catholic religious education today retains prominent motifs of liberation and social justice. But this is judged to be not prominent enough in current Australian Catholic diocesan religion curricula.

Critical interpretation is a starting point for what Warren ${ }^{33}$ has called cultural agency. He proposed that one of the aims for religious education is to encourage and skill young people to go beyond being passive consumers of culture to become active constructors of culture. This acknowledges that cultural meanings are socially constructed and open to evaluation, not something that is a given, and hard to identify and change.

A part of critical interpretation and evaluation of culture needs a religious viewpoint; this can show how Catholicism, and religions generally, provide important values as reference points for questioning the authenticity of mediaconditioned imaginations of the world, and of human development, that have such a strong influence on young people. This challenge for religious educators was evident in the exhortation of Pope John Paul II: to develop your culture with wisdom and prudence, retaining the freedom to criticise what may be called the 'cultural industry', remaining all the while deeply concerned with truth ... faith will ask culture what values it promotes, what destiny it offers to life, what place it makes for the poor and the disinherited with whom the Son of Man is identified, how it conceives of sharing, forgiveness and love $\mathrm{e}^{34}$.

What is written here about critical interpretation and evaluation of culture in Catholic religious education is not new. It has a long history. It was prominent in the period of rapid change in religious education after the Second Vatican

30 P. Freire, Pedagogy of the oppressed, New York 1971, Herder \& Herder; P. Freire, Education for critical consciousness, New York 1980, Continuum.

31 A. Darder, M. Baltodano \& R. D. Torres (Eds), The critical pedagogy reader, New York 2003, RoutledgeFalmer.

32 T. H. Groome, Christian religious education: Sharing our story and vision, San Francisco 1980, Harper \& Row; T. H. Groome, Sharing faith: A comprehensive approach to religious education and pastoral ministry: The way of shared praxis, San Francisco 1991, Harper; T. H. Groome, Educating for life: A spiritual vision for every teacher and parent, Allen 1998, TX, Thomas More.

33 M. Warren, Communications and cultural analysis: A religious view, Westport, CN 1992, Bergin \& Garvey; Cf. Williams R., Problems in materialism and culture, London 1980, Verso.

34 Pope John Paul II, Homily, University of Laval Stadium Quebec City, "Canadian Catholic Review", October 1984, p. 324. 
Council, especially in the quest for personalism and relevance in class discussions of personal and social issues ${ }^{35}$. The discussion of issues was also evident in British state school religious education in the mid-1960s as influenced by the writings of Loukes ${ }^{36}$. But what proved problematic in both contexts at the time was the pedagogy. Uninformed discussion often amounted to little more than sharing ignorant opinions. And usually this could not sustain student interest for too long. Also, this approach was perceived by students as a low grade pedagogy in a subject that had little academic status; and, as explained by Crawford \& Rossiter $^{37}$ its potential educational value was subverted by what they called the "psychology of the learning environment". The crucial missing ingredient was a high grade pedagogy - a serious study of the issues, in the light of up-to-date expert information. Here discussion was one useful part of the whole study exercise - like an informed debate - and not like a time-filling, non-directed, relatively purposeless activity.

Specific attention will now be given to pedagogy.

\section{Implications for pedagogy and content}

If religious education is to be a credible subject in the curriculum, then it needs to engage students with nothing less than the same sort of intellectual challenges that they accept as normal in other key learning areas. In other words, it needs to be academically challenging from Year 1 to Year 12, acknowledging that what 'academic' means at different levels needs to be determined. In primary and junior secondary classes, academic can well include experiential, hands-on

${ }_{35}$ G. M. Rossiter, Historical perspective on the development of Catholic Religious Education in Australia: Some implications for the future, "Journal of Religious Education" (1999) 47 (1), p. 5-18; M. L. Crawford \& G. M. Rossiter, Reasons for living: Education and young people's search for meaning, identity and spirituality. A handbook, Melbourne 2006, Australian Council for Educational Research, p. 391.

36 H. Loukes, Teenage religion, London 1961, SCM Press; H. Loukes, New Ground in Christian education, London 1965, SCM Press; H. Loukes, Teenage morality, London 1973, SCM Press; see also: M. L. Crawford \& G. M. Rossiter, Reasons for living: Education and young people's search for meaning, identity and spirituality. A handbook, Melbourne 2006, Australian Council for Educational Research.

37 M. L. Crawford \& G. M. Rossiter, Reasons for living: Education and young people's search for meaning, identity and spirituality. A handbook, Melbourne 2006, Australian Council for Educational Research, p. 307-309. 
learning methods (like scripted dramas, role plays, cartoon summaries, student audio-visual productions, group work, etc.).

For students who may readily tend to perceive religion lessons as extended sermons, in a pejorative sense, there is an even greater need than in other subjects / learning areas to demonstrate that the study of religion is open and inquiring - concerned with exploring the content and issues - and not with the 'getting of Catholicism': hence the need for a content-rich, student-centred, research-oriented pedagogy. Such a pedagogy can be applied to both the content areas referred to above: Catholic traditions and critical interpretation/ evaluation of culture.

A critical pedagogy is understandably appropriate for the interpretation and evaluation of cultural meanings. Personal and social issues can become topics for investigation. It is easier for the students to explore social issues which are more 'out there'; hopefully, this can prompt them to reflect on personal implications.

Both individual and group research methods can be used. Here the students have the power as investigators. This approach is clearly different from a didactic one where the teacher usually provided the information. This sort of critical, inquiring pedagogy is consistent with what students are experiencing elsewhere in the curriculum; and this is a good thing for religious education.

Careful attention needs to be given to the selection of issues to be investigated, and how these might be spread across the school religion curriculum. Firstly, it is appropriate to give more attention to the study of social issues at secondary level, especially in senior classes; however, a simpler critical approach is also needed at primary level. Students need to learn the skill of scrutinising cultural meanings through example investigations. If too many issues were studied, this would result in an unbalanced curriculum; it might also depress the students by giving too much attention to problems.

The critical interpretation and evaluation of social issues should not be limited to religious education; it should enter into learning areas across the whole curriculum as in a scheme proposed by Crawford \& Rossiter ${ }^{38}$ where three integrated approaches were used:

- Explicit, with both whole subjects - like religion, philosophy or ethics; and as parts of study units in regular subjects;

${ }^{38}$ M. L. Crawford \& G. M. Rossiter, Reasons for living: Education and young people's search for meaning, identity and spirituality. A handbook, Melbourne 2006, Australian Council for Educational Research, p. 304-315. 
- Contextual, where issues are touched on briefly in different learning areas or subjects without compromising the integrity of the principal subject matter; this approach postulates that values issues are often there in regular curriculum content, often just below the surface - they do not have to be introduced from outside; and

- General skills and consciousness-raising where all subjects contribute to the development of learning skills that carry over into personal learning for life.

While the author has no ready example of the results of school students' research on social issues, readers can examine a website with the presentations of classes of teachers in the Master of Religious Education program. They worked in groups investigating social issues in the same way they expected their students to conduct group mini-research projects ${ }^{39}$.

Problem posing content topics can also be used in the study of religious traditions, especially at secondary level. A practical example is given in Crawford \& Rossiter ${ }^{40}$. Different approaches to teaching the topic of the Rosary were described - some considered appropriate and others inappropriate. The recommended approach engaged junior secondary students in a research oriented class project entitled "Investigating the place of the Rosary in Catholic spirituality". The sub-questions were:- "What is the Catholic rosary? When was it invented? How did it develop over the centuries? How was it used in prayer, both historically and in modern times? Why is the rosary apparently dying out? If it dies out, will something valuable be lost - a place for meditative, repetitive prayers?" After examining material on the origins, history and development of the rosary, the students conducted a limited survey of Catholics they knew, particularly from the older generation, to see how the rosary was prayed and to find out how it contributed to spirituality. Further comparative information about Buddhist and Muslim rosaries was accessed before the class discussed its conclusions. In addition, there was an experiential component to the study where the students prayed the rosary together; and there was an optional rosary prayer session in the chapel in free time. This example showed that an open, inquiring approach often ended up with more content than could be handled

39 The presentations reporting the results of religion teachers' group research projects on social issues can be viewed on the site http://rel-ed.acu.edu.au/mre/636/research.html (04.05.2015).

40 M. L. Crawford \& G. M. Rossiter, Teaching religion in the secondary school: Theory and practice, Sydney 1985, Christian Brothers Province Resource Group, p. 80-81. 
in the time available; and while being informative, it did not come across as an exhortation to improve the rosary saying performance of pupils.

Other examples of issue and problem-oriented topics for studying religious content are provided in Crawford \& Rossiter ${ }^{41}$. The topic on the rosary was not controversial; however, if this approach was extended to include topics like women priests, new Christian interpretation of sexuality and contemporary interpretations of doctrines like original sin, atonement, salvation, the virgin birth, the immaculate conception etc., then it would be likely to prove unacceptable to a number of clergy and bishops. Here the approach would run into difficulty. Hence it is important to determine an appropriate level and extent of critical topics that could be a valuable part of the Catholic school religion curriculum. A systematic and critical study of theology is an adult task. And Catholic schools are not seminaries or theological colleges; their role is to introduce young people to theology and not to train them as theologians. Hence, the extent of controversial theological topics needs to be limited; still, a healthy, inquiring, critical approach can still be used appropriately throughout the religion curriculum.

Another related difficulty for religion teachers to negotiate is where the students themselves raise theological questions - their readiness to do this can be disconcerting for teachers who are unprepared. Here, teachers need to show an awareness of contentious theological issues, so that they are able to articulate briefly the various viewpoints, and direct students to some pertinent resources, even if it is beyond their scope to conduct an informative study of such topics. No matter what view religious authorities might take on trying to limit the scope of a critical approach in religious education, nothing will stop the students from questioning; not to acknowledge their questions or trying to 'fob' them off, would be counterproductive. Often they ask genuinely challenging questions about the logic and the meaning of religious teachings that need to be addressed. The issues raised in this paragraph require considerable further attention by Catholic religious educators.

While some religion teachers have made good use of a critical inquiring pedagogy in religious education, whether Catholic school and ecclesiastical authorities are ready to endorse its wider use in normative documents remains

${ }^{41}$ M. L. Crawford \& G. M. Rossiter, Reasons for living: Education and young people's search for meaning, identity and spirituality. A handbook, Melbourne 2006, Australian Council for Educational Research, p. 395. 
a crucial question. At times, religious authorities are afraid to do this because they feel it will encourage too much questioning by students, which might turn them away from the faith. On the contrary, it is considered that trying to eliminate questioning would be more off-putting for young people who find their cultural experience and education naturally saturated with questioning. A critical pedagogy that explores the evolution and change in theological doctrines can help students understand religious meanings in their original cultural context and how they have been reinterpreted in later times. This can engage them in some initial 'theologising'. Not to do this can leave them with simplistic and often literal interpretations of Catholic doctrines that they acquired when they were very young; and these teachings become eminently disposable in the students' eyes - or they become reasons for dismissing religion because the feel they have been deceived. Trying to develop some understanding of the changing meaning and function of doctrines within the Catholic theological system is an important aim for religious education.

The approach described above is not new to Catholic school religious education and can be observed in the practice of particular religion teachers; but how extensive it might be across the system remains unknown. The point that this article is trying to make is that this view of the role of the Catholic religion curriculum should be much more prominent than it is; and it should be focused on trying to enhance the human spirituality of pupils. A critical approach can be implied in social justice topics. Nevertheless, the main curriculum emphasis still remains on conserving the religious tradition - as if all will be well as long as 'good' theology and scripture are taught.

Catholic diocesan religion curricula are basically 'conservative' in the good sense of 'conserving' the tradition; hence the content topics cover all traditional theological content. But given contemporary youth spirituality, such curricula are just too 'tame' to attract much interest from young people. State based religion studies courses in Australia are also considered to be too tame, but for different reasons ${ }^{42}$. It may well be that diocesan authorities will not make any moves to encourage a critical approach in content and pedagogy. If this is the case, then the only way that the recommended re-orientation might occur would be when teachers at the school level make adjustments in the way they implement religious education.

${ }^{42}$ G. M. Rossiter, Historical perspective on the development of Catholic Religious Education in Australia: Some implications for the future, "Journal of Religious Education" (1999) 47 (1), p. 5-18. 


\section{The Person and the Challenges \\ 24 \\ Volume 5 (2015) Number 2, p. 5-32 \\ 5. Relationships between primary and secondary school religious education}

The argument in this article is based principally on the spirituality of youth and adults. Only limited attention will be given to children's spirituality; but it is hoped that this section will at least raise issues that prompt a more systematic response from primary school religious educators. While acknowledging significant differences between primary and secondary school religious education, which should be linked to differences between the spiritualities of children and adolescents, there is a need to avoid creating an unrealistic divide between the two. What is important is to see how the change between children's and adolescents' spirituality is gradual and nuanced.

As far as the religion curriculum in Catholic primary schools is concerned, this author judges that there is no need to change the basic content and pedagogy, which are directed to a hands-on, experiential approach which helps socialise children into the teachings and religious practices of Catholicism. There is scope for elements in a scaled down critical approach, but there is no need to develop this extensively at primary school level. However, religious education in the primary school needs to keep pace with the level of critical pedagogy and critical content that pupils normally experience in other learning areas. The emerging intellectual and critical faculties of children should not be ignored but enhanced. Children at this level can still ask challenging questions about the meaning of religious teachings that would have been unheard of from the older generations when they were that age. One simple example of critical interpretation of culture in a junior primary class was evident where the teacher had groups of students run a regular Friday short session on 'Commenting on what is happening in the world news this week'.

The theory for Catholic primary school religious education, as well as anecdotal reports from teachers suggest that children are often very responsive in religious education at this level - they are a delight to teach ${ }^{43}$. They enjoy religious education and are enthusiastic about religious activities. In the light

43 J. W. Berryman \& D. Strong, How to lead Godly play lessons, Denver 2007, Living the Good News; Catholic Education Archdiocese of Brisbane, 2007; H. Healy, B. Hyde \& R. Rymarz, Making our way through primary RE: A handbook for religious educators, Tuggerah, NSW 2004, Social science Press; B. Hyde \& R. Rymarz, First steps in religious education, Ballan Vic. 2008, Connor Court Publishing; M. Ryan \& J. Grajczonek, An inspired tradition: Religious education in Catholic primary schools today, Brisbane 2007, Lumino Press. 
of adolescent spirituality, where there is a prominent disinterest in religion ${ }^{44}$, this raises a number of questions about the relationship between primary and secondary religious education, for example:

- How does the apparent responsive religiosity of children square with the disinterest in religion and religious education often shown by teenagers? ${ }^{45}$

- Is religious education successful at primary level but failing in secondary classes?

- Is there something missing in primary religious education because as children mature they lose interest?

Very young children are open, impressionable and trusting; usually they go along with whatever their teachers tell them or ask of them. No matter what view of religion prevails in their homes, they may happily enter into the religious world view created at school, and their participation suggests that they are engaging effectively in their religious socialisation. At this stage of development, their overt religious spirituality at school is vicarious and imitative ${ }^{46}-$ they can readily assimilate the religious meanings and practices in the Catholic primary school. This is not implying that their spirituality is not personal and authentic. At school, they seem to accommodate readily to a different view of religion from that which prevails at home. Religion / religious education at school is like a 'second language' to that spoken at home. And, from the children's point of view, mostly there appears to be no significant conflict. Inevitably, the spectrum of their responses changes as they get older. The transition from a child's to adolescent spirituality remains a significant topic that needs much further consideration and research. Nevertheless, research studies do suggest that most children will eventually end up with the same sort of spirituality / religiosity that is evident in their parents ${ }^{47}$. As summarised on the back cover

${ }_{44}$ M. Mason, A. Singleton \& R. Webber, The spirit of Generation Y: Young people's spirituality in a changing Australia, Melbourne 2007, John Garratt.

45 M. L. Crawford \& G. M. Rossiter, Missionaries to a teenage culture: Religious Education in a time of rapid change, Sydney 1988, Christian Brothers Province Resource Group; M. Flynn and M. Mok, Catholic schools 2000: A longitudinal study of year 12 students in catholic schools, 1972-1982-1990-1998, Sydney 2002, NSW Catholic Education Commission.

46 J. W. Fowler, Stages of faith: The psychology of human development and the quest for meaning, San Francisco 1981, Harper \& Row.

47 C. Smith \& M. L. Denton, Soul searching: The religious and spiritual lives of American teenagers, Oxford 2005, Oxford University Press; M. Mason, A. Singleton \& R. Webber, The spirit of Generation Y: Young people's spirituality in a changing Australia, Melbourne 2007, John Garratt. 
of Smith \& Denton's ${ }^{48}$ report on the US national survey of youth and religion "young people from every corner of the culture echo their parents' religiosity to an astonishing degree".

As children mature through adolescence, for many of them, their cultural religious meanings seem to fade into the background as they become more autonomous in their thinking and more self-reliant in their behaviour. They may then identify more readily with negative views of religion in the culture. But it is not that they are consciously putting their religion aside or even becoming anti-religious. Rather, religious meanings are just eclipsed by more immediate cultural meanings about lifestyle, feel-good, looks, friendship and entertainment. As Smith \& Denton noted: "In the ecology of... adolescents' lives, religion clearly operates in a social-structurally weaker position, competing for time, energy, and attention and often losing against other, more dominant demands and commitments, particularly school, sports, television, and other electronic media... Religion simply occupies a largely losing structural position when it comes to most adolescents' obligations, schedules, routines and habits. When it comes to institutions possessing opportunities to form the lives of youth, religion is not among the more advantaged players" ${ }^{\prime 49}$.

At a time when life seems to be opening up explosively for them, religion appears to have little to say that is relevant to their concerns.

This decline in religiosity does not mean that primary school religious education has failed - neither should blame be attributed to the secondary school. There are cultural and developmental influences at work that cannot be superseded and neutralised by school religious education. What was done in primary school in the way of acquainting children with their religious tradition was valuable in its own right; and it may well leave an enduring imprint in their human spirituality. Similarly, secondary religious education is not at fault for undoing the good work done in the primary school. Here too, even where there may be little interest in studying religion, there could be a valuable, but not necessarily identifiable, contribution to young people's spiritual development.

It is worth considering that children may build up an attractive experience and image of what religion is like for a child, and if this is not updated as they

48 C. Smith \& M. L. Denton, Soul searching: The religious and spiritual lives of American teenagers, Oxford 2005, Oxford University Press.

49 C. Smith \& M. L. Denton, Soul searching: The religious and spiritual lives of American teenagers, Oxford 2005, Oxford University Press, p. 161. 
grow older, they may gradually detach from their childlike view of religion just as they naturally leave childhood behind. Religion might then remain like a pleasant childhood relic - while not relevant to the world of the adolescent and the adult. This interpretation needs further investigation. If this is true to some extent, then their ultimate view of religion (and the Church) will be influenced mainly by their perception of religion itself and not of religious education.

\section{Conclusion}

This article proposed that, in the light of significant changes in the landscape of contemporary spirituality, there is need for a 'big picture' re-orientation of Catholic school religious education to be more relevant to young people's spirituality, whether or not they become active in Catholic parish life. Teaching to hand on the Catholic tradition should retain its prominent place because, for all young Catholics, access to the spiritual resources of the Church is a birthright. However, especially at secondary level, religious traditions should be taught with more problem-posing, student-centred, research-oriented content and pedagogy.

The component that needs strengthening both in normative Catholic religious education documents and in classroom practice is the critical interpretation and evaluation of cultural meanings - helping young people become more discerning of the shaping influence that cultural meanings have on thinking and behaviour. This can help them probe the spiritual and moral dimension to life in times when it can easily be obscured in a society preoccupied with lifestyle and individual well-being, where the dominant, and relatively unquestioned mood is that this can be achieved happily through excessive consumerism.

In this way, Catholic schools can offer their students unconditionally a religious education that enhances their spirituality. It can help them develop skills that will assist in charting their way meaningfully through the maze of cultural meanings in society. In addition, this approach may be the best way of presenting the option of a more formal and ongoing engagement with the Church.

This critical approach is consistent with developments in the general curriculum where increasingly there are opportunities for pupils to study values related issues.

A critical evaluative approach is not new to Catholic religious education; it has had a long history in evangelisation and Catholic social teaching - but this was applied mainly in adult education. It now needs more prominence in 
school religious education. A more human focus is not necessarily replacing or neglecting the religious dimension. It actually has a strong New Testament basis. The Gospel accounts show that the historical Jesus was specially concerned with the lives and social situation of the 'little people' - the marginalised and the poor. Central to Jesus' praxis was addressing the social and religious problems that people faced. If anything, he is pictured as more concerned about people's basic welfare and human spirituality than with formal religiosity. It would seem incongruous to think of Jesus concentrating a lot of attention on how to improve on the poor synagogue attendance of the Jewish youth of his time! His overriding concern for people's human spirituality was reflected in John's gospel as follows "I have come that they may have life, and life to the full"

Finally, it is helpful to see that the proposed re-orientation of religious education is consistent with the constitution of Australian catholic schools. In this country, Catholic schools are not like seminaries that are totally owned and controlled by the Catholic Church (even though some have expectations of the schools as if they were exclusively ecclesiastical institutions). Because they are supported mainly by Government funding, they are semi-state schools, constituted as a state-private joint venture in education - comparable with state involvement in the funding of church-sponsored hospitals, social service and aged care facilities. Australian Catholic schools reflect a partnership between the Catholic Church, Government and parents. They therefore have a civic responsibility and accountability to the wider community to educate young citizens. This constitution makes it appropriate that Catholic schools be 'opento-all' and not just for Catholics. The proposed approach to religious education is congruent with an open-to-all mission. It is basically an open, inquiring study of the spiritual and moral dimension to life, with an understandable emphasis on Catholicism appropriate for a school sponsored by the Catholic Church. This view challenges thinking that considers that Catholic schools should only enrol students from regular mass-going families. While the schools were originally designed to cater for Catholics, they now include children who are nominally Catholic as well as some who are not Catholic. It is envisaged that some modification could readily be made in content to take into account the presence of children who are not Catholic. While this question needs considerable further attention, it is proposed that most of what should be done in the religion curriculum would be of value for the spirituality of religious

50 John, 10:10. 
and non-religious Catholics, as well as for religious and non-religious young people from other traditions, including non-Christian religions. In studying religious traditions, there could be scope for students who were not Catholic to do their study/research on their own tradition. The components of critical interpretation of culture should be applicable to all students no matter what their religious affiliation. Initial work on these questions has been done in Australia by Welbourne and Chambers, Grajczonek \& Ryan ${ }^{51}$.

The idea of Catholic religious education enhancing young people's human spirituality is a valuable expression of the way Catholic schools might contribute to Australian education generally; it provides young Australians with an education that seeks to give special attention to the spiritual/moral dimension. This thinking is a practical example of Catholic schooling making a valued contribution to the common good. Hence, the writings about Catholic schools and the common good are particularly pertinent to the arguments advanced here ${ }^{52}$.

There is no guarantee that the proposals here will solve the problems completely; there is no formula that will automatically engage students in religious education and transform their spirituality; and how successful the recommended approach might be could not be measured in the short term. Nevertheless, the re-orientation has tried to take serious account of contemporary youth spirituality.

Catholic schools ought to be centres of Catholic culture for the benefit of their staff, students and families. And a prominent part of this Catholic culture should be concerned with the critical interpretation and evaluation of the wider cultural meanings that have a conditioning influence on personal, social life and political life.

51 L. Welbourne, Inclusive admissions policies to Catholic schools: Implications for religious education, "Journal of Religious Education" (2003) 51 (1), p. 1-2; M. Chambers, J. Grajczonek \& M. Ryan, The presence and place of students who are not Catholics in Catholic schools: An analysis of official church documents, "Journal of Religious Education" (2006) 54 (1), p. 2-9.

52 A. S. Bryk, V. E. Lee, P. B. Holland, Catholic schools and the common good, Cambridge 1993, Harvard University Press; T. H. McLaughlin, J. O'Keefe \& B. O. O'Keefe (Eds.), The contemporary Catholic school: Context, identity, and diversity, London 1996, Routledge. (Included papers from the conference at St Edmund's College in Cambridge on "The contemporary Catholic school and the common good", 1993); D. Hollenbach, The common good, pluralism and Catholic education, in: McLaughlin et al., The contemporary Catholic school: Context, identity, and diversity" (1996), p. 89-104; J. C. Conroy (Ed.), Catholic education, inside out, outside in, Dublin 1999, Lindisfarne; J. K. Donlevy, The common good: the inclusion of non-Catholic students in Catholic schools, "Journal of Beliefs and Values" (2008) 29 (2), p. 161-171. 


\section{Bibliography}

Adams K., Hyde B. \& Woolley R., The spiritual dimension of childhood, London 2008, Jessica Kingsley.

Berryman J. W. \& Strong D., How to lead Godly play lessons, Denver 2007, Living the Good News.

Bryk A. S., Lee V. E., Holland P. B., Catholic Schools and the Common Good, Cambridge 1993, Harvard University Press.

Catholic Bishops of NSW \& ACT, Catholic schools at a crossroads: Pastoral letter of the Bishops of NSW and the ACT, Sydney 2007, Catholic Education Office.

Catholic Education Archdiocese of Brisbane, Religious education: Curriculum guidelines for the early years, Brisbane 2007, Catholic Education Office.

Chambers M., Grajczonek J. \& Ryan M., The presence and place of students who are not Catholics in Catholic schools: An analysis of official church documents, "Journal of Religious Education" (2006) 54 (1), p. 2-9.

Coles R., The spiritual life of children, London 1992, Harper Collins.

Conroy J. C. (Ed.), Catholic education, inside out, outside in, Dublin 1999, Lindisfarne.

Crawford M. L. \& Rossiter G. M., Teaching religion in the secondary school: Theory and practice, Sydney 1985, Christian Brothers Province Resource Group.

Crawford M. L. \& Rossiter, G. M., Missionaries to a teenage culture: Religious Education in a time of rapid change, Sydney 1988, Christian Brothers Province Resource Group.

Crawford M. L. \& Rossiter G. M., The secular spirituality of youth: Implications for religious education, "British Journal of Religious Education" (1996) 18 (3), p. 133-143.

Crawford M. L. \& Rossiter G. M., Reasons for living: Education and young people's search for meaning, identity and spirituality. A handbook, Melbourne 2006, Australian Council for Educational Research.

Darder A., Baltodano M. \& Torres R. D. (Eds), The critical pedagogy reader, New York 2003, RoutledgeFalmer.

De Lors J., (UNESCO), Learning the treasure within, Paris 1996, UNESCO International Commission on Education for 21 st Century.

Donlevy J. K., The common good: the inclusion of non-Catholic students in Catholic schools, "Journal of Beliefs and Values" (2008) 29 (2), p. 161-171.

Flynn M. and Mok M., Catholic schools 2000: A longitudinal study of year 12 students in catholic schools, 1972-1982-1990-1998, Sydney 2002, NSW Catholic Education Commission.

Fowler J. W., Stages of faith: The psychology of human development and the quest for meaning, San Francisco 1981, Harper \& Row.

Frankl V., Man's search for meaning, London 1964, Hodder \& Stoughton.

Freire P., Pedagogy of the oppressed, New York 1971, Herder \& Herder.

Freire P., Education for critical consciousness, New York 1980, Continuum.

Fuller R. C., Spiritual, but not religious: Understanding unchurched America, New York 2001, Oxford University Press.

Groome T. H., Christian religious education: Sharing our story and vision, San Francisco 1980, Harper \& Row. 
Groome T. H., Sharing faith: A comprehensive approach to religious education and pastoral ministry: The way of shared praxis, San Francisco 1991, Harper.

Groome T. H., Educating for life: A spiritual vision for every teacher and parent, Allen 1998, TX: Thomas More.

Hay D \& Nye R., The spirit of the child, London 1998, Harper Collins.

Healy H., Hyde B. \& Rymarz R., Making our way through primary RE: A handbook for religious educators, Tuggerah, NSW 2004, Social science Press.

Hill B. V., A Time to Plant and a Time to Uproot: Values Education in the Secondary School, Sydney 1990, Sydney Anglican Education Commission.

Hollenbach D., The common good, pluralism and Catholic education, in: McLaughlin et al., The contemporary Catholic school: Context, identity, and diversity (1996), p. 89-104.

Hyde B., Children and spirituality: Searching for meaning and connectedness, London 2008, Jessica Kingsley.

Hyde B. \& Rymarz R., First steps in religious education, Ballan Vic. 2008, Connor Court Publishing.

Kenyon D., What constitutes success in classroom religious education? A study of secondary religion teachers' understandings of the nature and purposes of religious education in Catholic schools, Unpublished PhD Thesis, Australian Catholic University, Sydney 2010.

Loukes H., Teenage religion, London 1961, SCM Press.

Loukes H., New Ground in Christian education, London 1965, SCM Press.

Loukes H., Teenage morality, London 1973, SCM Press.

McLaughlin T. H., O'Keefe J. \& O'Keefe B. O. (Eds.), The contemporary Catholic school: Context, identity, and diversity, London 1996, Routledge. (Included papers from the conference at St Edmund's College in Cambridge on "The contemporary Catholic school and the common good", 1993).

Mason M., Singleton A. \& Webber R., The spirit of Generation Y: Young people's spirituality in a changing Australia, Melbourne 2007, John Garratt.

Nipkow K. E., Pre-conditions for ecumenical and interreligious learning: Observations and reflections from a German perspective, Sydney 1991, Australian Catholic University Curriculum Research and Development Project in Religious Education.

Otto R., The idea of the holy: The idea of the holy: An inquiry into the non-rational factor in the idea of the divine and its relation to the rational (English 2nd Edn.), New York 1950, Oxford University Press.

Pope John Paul II, Homily, University of Laval Stadium Quebec City, "Canadian Catholic Review", October 1984, p. 323-325.

Pope Paul VI, Evangelii Nuntiandi (Evangelisation in the modern world), Homebush NSW, 1976, St Paul Publications.

Rossiter G. M., Religious education in Australian schools, Canberra 1981, Curriculum Development Centre.

Rossiter G. M., Historical perspective on the development of Catholic Religious Education in Australia: Some implications for the future, "Journal of Religious Education" (1999) 47 (1), p. 5-18.

Rossiter G. M., Religious education and the changing landscape of spirituality: Through the lens of change in cultural meanings, "Journal of Religious Education" (2010) 55 (2). 
Ryan M. \& Grajczonek J., An inspired tradition: Religious education in Catholic primary schools today, Brisbane 2007, Lumino Press.

Schweitzer F., Religious individualization: New challenges to education for tolerance, "British Journal of Religious Education" (2007) 29 (1), p. 89-100.

Smith C. \& Denton M. L., Soul searching: The religious and spiritual lives of American teenagers, Oxford 2005, Oxford University Press

Tacey D., Reenchantment: The new Australian spirituality, Sydney 2000, Harper Collins.

Tacey D., The spirituality revolution: The emergence of contemporary spirituality, Sydney 2003, Harper Collins.

Warren M., Source book for modern catechetics, Winona, MN 1983, St Mary’s Press.

Warren M., Communications and cultural analysis: A religious view, Westport, CN 1992, Bergin \& Garvey.

Warren M., Religious education and the task of cultural critique, "Religious Education" (1993) 88 (1), p. 68-79.

Welbourne L., Inclusive admissions policies to Catholic schools: Implications for religious education, "Journal of Religious Education" (2003) 51 (1), p. 1-2.

Williams K., The common school and the Catholic school: A response to the work of T. H. McLaughlin, "International Studies in Catholic Education" (2010) 2 (1), p. 19-36.

Williams R., Problems in materialism and culture, London 1980, Verso.

Wong T. P. \& Fry P. S. (Eds.), The human quest for meaning: A handbook of psychological research and clinical applications, Mahwah 1998, Lawrence Erlbaum. 